\title{
On the moroccan tsunami catalogue
}

\author{
F. Kaabouben ${ }^{1}$, M. A. Baptista ${ }^{2}$, A. Iben Brahim ${ }^{3}$, A. El Mouraouah ${ }^{3}$, and A. Toto ${ }^{1}$ \\ ${ }^{1}$ University Iben Tofail of Kenitra, Morocco \\ ${ }^{2}$ Instituto Superior de Engenharia de Lisboa, CGUL, IDL, Portugal \\ ${ }^{3}$ Institut National de Géophysique, CNRST, Morocco
}

Received: 31 March 2009 - Revised: 8 June 2009 - Accepted: 13 June 2009 - Published: 23 July 2009

\begin{abstract}
A primary tool for regional tsunami hazard assessment is a reliable historical and instrumental catalogue of events. Morocco by its geographical situation, with two marine sides, stretching along the Atlantic coast to the west and along the Mediterranean coast to the north, is the country of Western Africa most exposed to the risk of tsunamis. Previous information on tsunami events affecting Morocco are included in the Iberian and/or the Mediterranean lists of tsunami events, as it is the case of the European GITEC Tsunami Catalogue, but there is a need to organize this information in a dataset and to assess the likelihood of claimed historical tsunamis in Morocco. Due to the fact that Moroccan sources are scarce, this compilation rely on historical documentation from neighbouring countries (Portugal and Spain) and so the compatibility between the new tsunami catalogue presented here and those that correspond to the same source areas is also discussed.
\end{abstract}

\section{Introduction}

Morocco is considered the African country most affected by tsunamis generated by earthquakes (El Alami and Tinti, 1991). However, direct documentary sources are rather scarce in spite of the recent efforts to recover reliable historical sources. The earliest historical documents refer to an event in $218 \mathrm{BC}$ at Cadiz, close to the Morocco Atlantic coast, and to another in 1522, observed in Granada and Almeria, close to the Morocco Mediterranean coast (Mendonça, 1758), where violent sea agitation in Bades Ghomera, $36^{\circ} 16^{\prime} \mathrm{N}, 4^{\circ} 13^{\prime} \mathrm{E}$ on the mediterranean coast, was observed during this earthquake (El Mrabet, 1991). The most destructive historic tsunami known was generated by the 1 November 1755 "Lisbon" earthquake. It strongly af-

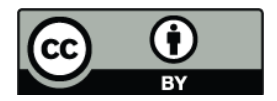

Correspondence to: M. A. Baptista (mabaptista@dec.isel.ipl.pt) fected the Atlantic coast of Morocco. The documents describe the devastation of several coastal dwellings, the destruction of boats and constructions and severe loss of human lives.

All known tsunami events in Morocco were generated by earthquakes. This fact makes earthquake catalogues the primary input for the production of a tsunami catalogue. ElMrabet (1991, 2005) compiled a review of historical seismicity of Morocco that still corresponds to the most comprehensive study and, for the case of the 1755 Lisbon earthquake and tsunami, Levret et al. (1991) made a systematic compilation of local sources. El-Alami and Tinti (1991) presented the first tsunami hazard study of Morocco based on a seismicity catalogue for the period (1901-1986). They computed an estimate for the tsunami potential, evaluating for a $0.5^{\circ} \times 0.5^{\circ}$ grid (Mediterranean domain) and $1^{\circ} \times 1^{\circ}$ grid (Atlantic domain), the mean recurrence time for potential tsunamigenic earthquakes. In the Atlantic domain they emphasized the importance of the source area close to SW Portugal where both the 1755 and the 1969 events are supposed to be generated. In the Mediterranean domain they identified two main source areas, one around the Alboran Sea and another close to the Algerian coast, between Oran and Mostaghanem (El Alami and Tinti, 1991).

Pelaez et al. (2007) presented recently a revision of the 1045-2005 earthquake catalogue for the area of Morocco including also the southernmost part of Spain and Portugal and the western region of Algeria. This catalogue includes, for both the Atlantic and the Mediterranean domains, a set of earthquake events, the epicentres of which are located offshore, and the moment magnitudes of which exceed 6, that can be considered as having tsunamigenic potential. Some of these events are already included in available tsunami catalogues (Tinti et al., 1999) and can be used as starting information to look for eventual tsunami observations in coastal areas. This preliminary list must be completed with events located further away, in the Atlantic and in the Mediterranean, but that are strong enough to generate noticeable tsunamis

Published by Copernicus Publications on behalf of the European Geosciences Union. 
Table 1. 1 November 1755 tsunami effects in several places along the Morocco coast. Locations are plotted in Fig. 1 (MID Maximum Inundation Distance).

\begin{tabular}{lccccl}
\hline Site & 1st movement & Run-up & MID & Wave Period & Reference \\
\hline Ceuta & up & $2.5 \mathrm{~m}$ & $2.5 \mathrm{~m}$ & $30 \mathrm{~min}$ & Gaz. Cologne, 1756 \\
Tanger & up & $15 \mathrm{~m}$ & $2000 \mathrm{~m}$ & $26 \mathrm{~min}$ & Gazette D'Amsterdam, 1756; Debrach, 1946; El Mrabet, 1991. \\
Assilah & - & $3 \mathrm{~m}$ & $>100 \mathrm{~m}$ & - & Sylvanus, 1755 El Mrabet, 1991 \\
Salé & down & - & $2000 \mathrm{~m}$ & - & \\
Rabat & - & $4 \mathrm{~m}$ & - & - & El Mrabet, 1991 \\
El Jadida & - & $2.5 \mathrm{~m}$ & - & - & Blanc, 2009 \\
Safi & up & $15 \mathrm{~m}$ & $1200 \mathrm{~m}$ & - & Anonymous, 1755; Anonymous 1756; Fowke, 1756 \\
\hline
\end{tabular}

in Morocco coasts, as is the case of the large strike slip tsunamigenic events generated along the western segment of the Africa-Eurasia plate boundary (Baptista et al., 2006; Kaabouben et al., 2008). This information can be obtained in particular from the instrumental and historical data of neighbouring countries.

In this study, we present a review of all tsunami events that are supposed to have affected the coasts of Morocco, either observed directly or supported by written documents or, simply events of the 20th Century, which were detected by coastal tide gauge stations. Most descriptions of the events do not allow presenting the available information in terms of quantitative parameters that can be used for modelling purposes or in the assessment of tsunami hazard; in spite of the scarcity and uncertainties inherent to the historical accounts a carefull revision of the available data concerning the 1755 tsunami is presented.

\section{The Atlantic domain}

The Eurasia-Africa plate boundary extends between the Azores and the western Mediterranean. It shows contrasting tectonic styles, going from a transtensional regime at west, close to the Azores, to transpressional one close to the Gibraltar Straight (Buforn et al., 1988; Morel and Meghraoui, 1996; Jiménez-Munt et al., 2001). The present day relative velocity between Africa and Eurasia plates along the SW Iberian margin is about $4 \mathrm{~mm} /$ year (Sella et al., 2002; Fernandes et al., 2007), close to the Ibero-maghrebian area. This slow convergence rate seldom generates large interplate earthquakes but historical and instrumental data support the conclusion that most of the larger events are able to generate important tsunamis.

In the last century, five events of magnitude $\mathrm{M}_{w}>7$ occurred in the Atlantic Domain: the 20 May $1931 \mathrm{M}=7.1$ (Moreira, 1968), the 8 May $1939 \mathrm{M}_{w}=7.1$ (Hirn et al., 1980), the 25 November $1941 \mathrm{M}_{w}=8.2$ (Udias and Arroyo. 1976), the 28 February $1969 \mathrm{M}_{w}=7.9$ (Buforn et al., 1988) and the 26 May $1975 \mathrm{M}_{w}=7.9$ (Buforn et al., 1988). In particular, the events of 1941, 1969 and 1975 generated tsunamis clearly recorded at the tide stations along the Morocco coasts, while the 1939 tsunami waves were recorded only at the Azores see Table 1.

A short description of the tsunamis in the Atlantic domain that might have affected Morocco is presented below.

\subsection{The 382 tsunami}

The 382 earthquake was felt around the Mediterranean (e.g. Sicily, Greece, and Palestine) and in Iberia. Brito (1597) describes briefly a tsunami: “(...) the rise of the sea subverted a part of the land and overtopped some islands (...) of which some rocks remained in the middle of the sea, which can be seen close or inside the ocean, mainly in Cape St. Vincent (SW Portugal)". If we accept Brito's (1597) description we can conclude that this event also surely affected Morocco. There are no local sources describing the event.

\subsection{The 22 May 881 tsunami}

In the historic study of El Mrabet (2005), the first event referred, which affected a broad region including Andalusia, Morocco from Tangier up to Tlemcen limits (Algeria), is dated 22 May, 881 (Abi Zaraa, in El Mrabet, 2005). The event was followed by a tsunami with major damage, documented in Arab references. Navarro-Neuman (1917) reported that the earthquake was followed by tsunami waves in the southern coasts of the Andalusia. The epicentre is supposed to be in the Mediterranean.

\subsection{The 1 November 1755 tsunami}

This is the most devastating event known in Morocco. It was observed along the North Atlantic coasts. The magnitude of the earthquake was recently re-evaluated from the macroseismic field as $\mathrm{M}_{w}=8.5 \pm 0.3$ (Solares and Arroyo, 2004). Several studies were published about the source location and the rupture mechanism but this is still a matter of debate (Johnston, 1996; Gutscher et al., 2006; Zitellini et al., 2001; Baptista et al., 2003). The most destructive waves were observed 
along the south and west coasts of Portugal along the Gulf of Cadiz and the Western coast of Morocco. A broad description of the 1755 tsunami in Morocco was compiled by El Mrabet (1991); it caused large damage to the coastal cities of Tangier, Asila, Larache, Mehdia, Salé, Rabat Mazagão, Safi and Santa Cruz (Agadir). The sea inundated circa $2 \mathrm{~km}$ inland along the coast (e.g. El Jadida, Safi, Essaouira), and in some places the water overtopped the city walls. In the harbors of Safi and Santa Cruz (now Agadir) the agitation of the sea was observed from 10:00 a.m. untill 06:00 p.m. causing damage to anchored ships (Anonymous, 1756). The information published in the document Verdadeira Relacion (1755) seems to be depicted from the letter of the priest in charge of the Fransciscanos Covent (Anonymous, 1756). In fact these two coeval documents should not be treated as independent as the texts in Verdadeira Relacion are extracts of authentic letters from each location, as it is specified in the tiltle ("sacado de las cartas, y relaciones autenticas da cada parage").

Ceuta: the traces of the earthquake are weak in spite of the fear which the waves caused in the population. The sea level rose approximately $2.5 \mathrm{~m}$ above the normal height of the waves during this season. After fifteen minutes the seawater moved back leaving a great number of fish and boats on the dry ground. The advance and the retreat of the sea continued until the next morning. According to the Cologne Gazette (1756) “(...) we felt here the same earthquake, we have been warned about from Spain and Portugal (...). The sea rose up 7 feet, a quarter later it runs down in such a way that a quantity of fish and boats became on dry sand (...)".

Tangier: in Tangier the impact of the earthquake was extremely strong. Seawater strongly rose until it reached the fortifications in a way which had never happened before (with a height reaching $15 \mathrm{~m}$ (Gazette d'Amsterdam, 1756; Debrach, 1946; El Mrabet, 1991). Water penetrated around $2 \mathrm{~km}$ and then retreated with the same speed until the bottom of the port emerged, leaving a great quantity of sand and fish on land. Tsunami waves repeated then eight times and agitation continued up to 06:00 p.m. with a decreasing its magnitude. The observations made at the time by Fowke (1756) are the following: "(...) the sea came up to the very walls, a thing never seen before, and went down directly with the same rapidity as it came up, as far as the place where the large vessels anchor in the bay, leaving upon the mole a great quantity of sand and fish (...)".

Assilah: the town of Assilah was affected by the earthquake and the tsunami as well. The influx of the waters (MID - Maximum Inundation Distance) covered half of the village (Anonymous, 1756; Anonymous, 1755) some casualties due to the tsunami were observed outside of the village, and the tsunami entered the village through one of the doors. An English boat, transporting corn, was thrown inside the city by the force of the waves; this increased the destruction, but not a single member of the crew was dead or injured. Another boat was found $100 \mathrm{~m}$ in land and with the withdrawal of the sea, the boat was left inland (El Mrabet, 1991). “(...) Here the sea reached more than half the town (...)" (Anonymous, 1755). The Gentleman's Magazine for the year 1755 page 564 reports: "(...) At Arzilla in Barbary the water rose nine feet, and a settee of the town foundered (...)".

Safi: according to the "Gazette of Amsterdam of 26 December 1756, the sea invaded the town of Safi up to the mosque". The ancient medina in Safi as well as the acient mosque is located circa $1.5 \mathrm{~km}$ from the sea. The tidal wave of the tsunami returned back and forth 18 times. We can quote from a coeval source (Anonymous, 1755; Anonymous, 1756). "(...) In the harbors of Safi and Santa Cruz (Agadir) the tsunami caused severe destructions; and damage in the buildings and houses, buried much people: the devastation was increased by the alteration of the Sea, that from ten o'clock of the day, up to six in the afternoon keep ebbing and receding impetuously, with similar acceleration, uncovering the bottom of the harbors, where ships and boats were anchored, submerging and damaging some of them (...)"; A letter written by the Governor of Gibraltar, describing the earthquake in "Barbary" report for Safi: (...) the sea came up as far as the great mosque, which is within the great cityand at great distance from the sea (...)" (Fowke, 1756). In order to estimate the maximum inundation distance the location of the old mosque was used as reference and we conclude that this distance is circa $1.2 \mathrm{~km}$.

Sale: the Letter of General Fowke Governor of Gibral$\operatorname{tar}(1756)$ says: "There happened a very great damage, several houses having fallen down. The waters came up with such rapidity, that they come into the city, and at their falling down, great quantities of fish were found in the streets and many persons were drowned (...) The sea strongly advanced at high speed to the interior of the city until it reached the interior of the shops. According to the same letter 2 ferries overset in the river and many persons were drowned. That was crossing the river The water penetrated inland and drowned all those which were out of the city walls. It destroyed three boats. The various sources (Kadiri, 1982) report unanimously that these boats transported 200 Moroccans. The advance of the sea coincided with the departure of a "caravan" transporting merchandise, where all men and camels were lost. After the withdrawal of the sea, a large amount of fish was left in dry land and a lot of peuple were injured (El Mrabet, 1991). “(...) the earthquake caused similar damage, and casualties in the city of Salé, and the sea inundated all the streets (...)" (Anonymous, 1755; Anonymous, 1756). In order to estimate the maximum inundation distance the location of the city walls was used as reference. Figure 2 shows the location of the city walls (fortress walls) that surrounded the old city of Sale. Approximate distances to the sea are shown; these values show that according to the historical description the maximum inundation distance should not be evaluated in more than $2000 \mathrm{~m}$, in spite of the numbers published in Arab sources. 


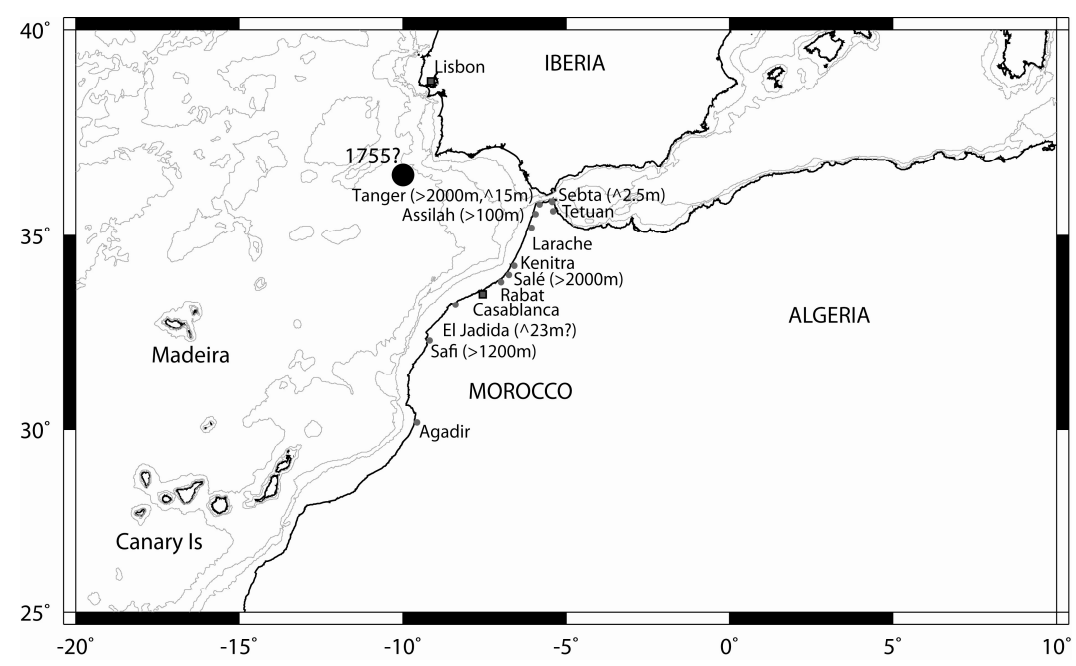

Fig. 1. Villages damaged by the 1755 tsunami. Run-up and Run-in values in meter obtained from historical descriptions.

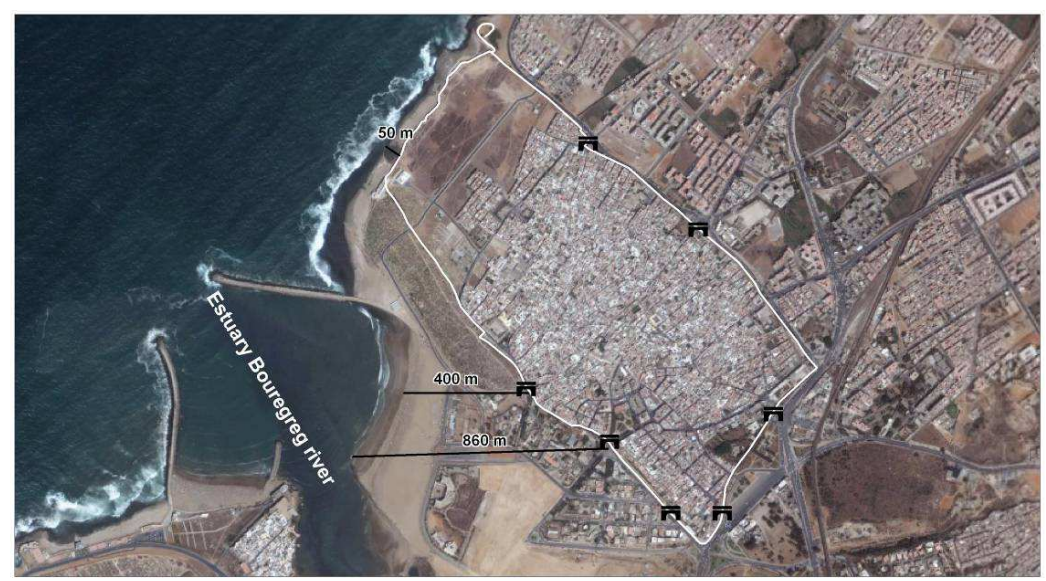

Fig. 2. Location of the city walls of Sale area (red line). The Medina is located inside the wall, and approximately $860 \mathrm{~m}$ away from the sea. From the available description we estimate the maximum inundation distance as $2000 \mathrm{~m}$.

Rabat: the town of Rabat suffered like all the others along the coast. The sea transgressed its normal limit at 04:00 p.m. The inhabitants believed that the sea would invade the whole city and two hundred people were drowned in Rabat (El Mrabet, 1991).

El Jadida (Mazagan): the concern of the inhabitants increased when the sea started to flow quickly, breaking the doors of the barricades, until reaching the square. According to a local merchant the sea overtopped the city walls, circa 75 feet (approximately $22.5 \mathrm{~m}$ ) (El Mrabet, 1991); After, the sea withdrew and leaving an enormous amount of fish in dry land, devastating and eroding the ground left some rocks uncovered. The water destroyed the crops and the king's fleet. Three people drowned; the sea overflow continued up to 02:00 p.m. (Gazeta de Lisboa, Janeiro 1756; Goulven, 1917). The run up value presented in Table 1 is $22.5 \mathrm{~m}$ according to El Mrabet (1991), is an extreme high value and would have mean the total destruction of the city (see Fig. 3). Blanc (2009) carefully discusses the different information sources for El Jadida 1755 maximum run-up and concludes for an amplitude of $2.5 \mathrm{~m}$ similar to other places on the Moroccan coasts.

From this historical description of the tsunami behaviour on the Moroccan coast, we try to dress a table with available quantitative parameters see Table 2, and we establish the map of the penetration of water in land (maximum inundation distance) and the rise of the waves (run up values) for the 1755 tsunami event on Moroccan coast see Fig. 1.

\subsection{The 31 March 1761 tsunami}

The 31 March 1761 earthquake was felt in Lisbon at noon, alarming the inhabitants and throwing down ruins of the prior 1 November 1755 earthquake. According to several coeval sources the earthquake was followed by a tsunami that was 
Table 2. Travel-time and amplitudes of the tsunami waves generated by the 25 November 1941 earthquake, as observed at the tide stations of Casablanca and Mogador.

\begin{tabular}{lcc}
\hline Parameters & Casablanca & Essaouira \\
\hline Arrival time & $20: 06-20: 32$ & $20: 06$ \\
Travel-time & $02: 02$ & $02: 02$ \\
Wave polarity & - & Down \\
Maximum amplitude (m) & 0.25 & 0.45 \\
\hline
\end{tabular}

observed as far as Cornwall (UK), Cork (Ireland) and Barbados (Caribbean). A recent revision of the historical data supported by numerical hydrodynamic modelling (Baptista et al., 2006) concluded that its epicentre was probably located around $34.5^{\circ} \mathrm{N} 13^{\circ} \mathrm{W}$ and that its magnitude was close to 8.5. The tsunami was observed in Lisbon, Madeira Island, and northern Europe and as far as Barbados (Mason, 1761). Because the event is confirmed in several localities especially in the Portuguese coasts and the epicentre estimated to be near to the Moroccan coast. As late as 1773, the "Journal Historique" clearly mentioned this March 1761 tsunami in Cadiz. It was also observed as far away as Kinsale in the United Kingdom (Borlase, 1762; Baptista and Miranda, 2009). So we conclude that it was most probably observed in Morocco.

\subsection{The 25 November 1941 tsunami}

This submarine earthquake in the Atlantic, was strongly felt on 25 November 1941 at 17:04 (GMT) in the Azores, in the Iberian Peninsula, in Morocco, Switzerland, England and USA. It caused a tsunami wave recorded at Casablanca and Essaouira (Morocco); Cascais, Lagos, Madeira, Ponta Delgada (Portugal) Moreira (1968). There are mareograms available for the tide stations of Casablanca and Mogador (Essaouira) where the tsunami wave arrived at 20:06 (UT) with maximum amplitude of $0.25 \mathrm{~m}$ (Casablanca) and $0.45 \mathrm{~m}$ (Mogador).

\subsection{The 28 February 1969 tsunami}

This is the most important event, which occurred last century, in terms of impact. The tsunami was recorded in Portugal mainland, Azores, Spain, Canary Islands and Morocco (Baptista et al., 1992; Heinrich et al., 1994; Gjevik et al., 1997; Rabinovich et al., 1998). Seaquakes were reported in Portuguese newspapers like "Diário de Noticias". Portuguese fishermen reported agitation of the sea (Diário da Manhã, 1969). The reduced number of eyewitness reports is certainly due to the fact that the earthquake occurred during the night, at 02:40.

The Moroccan newspaper "Al Alam" of the 1 and 2 March 1969 reported the behavior of people; in Rabat, Sale and Marrakech: distressed by the strong shock, they abandoned

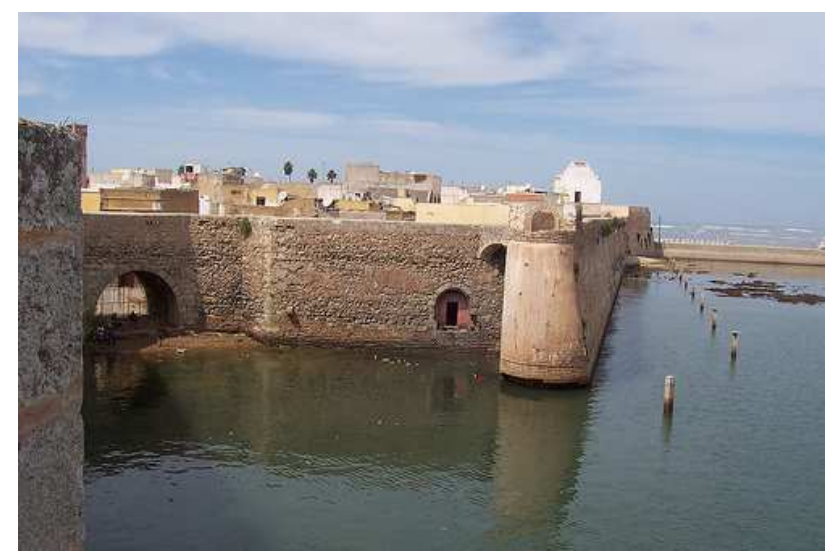

Fig. 3. El Jadida city walls and its sea gate. The maximum run-up of $22.5 \mathrm{~m}$ is incompatible with most historical sources (see Blanc, 2009).

houses, stayed outside for two nights. The newspaper reports strong agitation of the sea in Rabat and Sale during the night. The same reference shows the picture of the clock of the light house of the Casablanca stopped at the time of shaking recording so the exact time of the earthquake. We present also the tide gauge record of the harbor of Casablanca, where the tsunami amplitude can be estimated as $0.9 \mathrm{~m}$ in this station.

\subsection{The 26 May 1975 tsunami}

At 09:11:53(UT) a strike slip earthquake with $\mathrm{M}_{w}=7.9$ and epicentre located $200 \mathrm{~km}$ south of Gloria Fault (Buforn et al., 1988; Lynnes and Ruff, 1986), generated a small amplitude tsunami recorded in Portugal - Cascais and Lagos; Spain - Cadiz and Azores - Horta and Ceuta (Baptista et al., 1992; Kaabouben et al., 2008), where it showed an amplitude of only $0.04 \mathrm{~m}$. The maximum amplitude observed is $0.76 \mathrm{~m}$ (peak to peak) in the tide gauge of Horta (Faial Island, Azores). The event was studied en detail by Kaabouben et al. (2008).

\section{The mediterranean domain}

In the Alboran sea and in the Betics, east of the Strait of Gibraltar, earthquakes are small in magnitude and their epicentres are distributed in a broader sector covering the Alboran sea, the southern Spain and the northern Morocco. The southernmost limit of this continuous seismicity area extends towards the east, to the north of Algeria and Tunisia till the Calabria arc in Sicily. Earthquake magnitudes are relatively small or moderate. The most recent tsunami event took place on the 21 May 2003, as the consequence of an $\mathrm{Mw}=7$ earthquake generated; the tsunami was detected in the western Mediterranean basin, deeply affecting the Baleares Islands. 
Table 3. List of possible tsunamis on Moroccan coasts. We indicate, for each case, the generation of a noticeable tsunami, the availability of historical documents and maregrams in Morocco and the likelihood classification attributed in GITEC catalogue (Tinti et al., 1999); Lon Longitude, Lat - Latitude, Reliability according to Sieberg-Ambraseys scale.

\begin{tabular}{lcccccclccc}
\hline Year & Month & Day & Hour & Min & Longitude & Latitudee & Souce Area & Mw & Reliability & Source \\
\hline 382 & - & - & - & - & -1000 & 36.00 & South West Iberia & - & 2 & 3,4 \\
881 & 5 & 22 & & - & & & West Mediterranean & - & 4 & 1 \\
1522 & 9 & 22 & 10 & - & -02.66 & 36.97 & West Mediterranean & 6.5 & 4 & 1 \\
1680 & 10 & 9 & 7 & - & -04.60 & 36.80 & West Mediterranean & 6.8 & 4 & 1 \\
1733 & - & - & - & - & - & - & West Mediterranean & & 0 & 19 \\
1755 & 11 & 1 & 10 & 16 & -1000 & 36.50 & South West Iberia & 8.7 & 4 & $1,3,5,6,7,8$ \\
1761 & 3 & 31 & 12 & 15 & -13.00 & 34.50 & Gloria Fault & 8.5 & 3 & 2,9 \\
1790 & 10 & 9 & 1 & 15 & -00.60 & 35.70 & West Mediterranean & 6.7 & 1 & 1 \\
1856 & 8 & 21 & 21 & 30 & +05.72 & 36.83 & West Mediterranean & - & 0 & 20 \\
1941 & 25 & 11 & 18 & 04 & -18.98 & 37.42 & Gloria Fault & 8.2 & 4 & 6,10 \\
1969 & 2 & 28 & 2 & 40 & -10.57 & 36.01 & South West Iberia & 7.9 & 4 & $11,12,13,14,15,16,17$ \\
1975 & 5 & 26 & 9 & 11 & -17.56 & 35.98 & Gloria Fault & 7.9 & 4 & 11,18 \\
1980 & 10 & 10 & 12 & & +01.68 & 36.28 & West Mediterranean & 5.8 & 0 & 20 \\
2003 & 5 & 21 & 18 & 44 & +03.08 & 36.80 & West Mediterranean & 7.0 & 0 & $21,22,23$ \\
\hline
\end{tabular}

Sources: (1) El Mrabet (1991, 2005); (2) Baptista et al. (2006); (3) Catalogo GITEC; (4) Sousa (1678); (5) Gazette de Cologne (1756); (6) Debrach (1946); (7) Gazette d'Amsterdam (1755); (8) Verdadera Relacion (1756); (9) Le Journal Historique (1773); (10) Moreira (1968); (11) (Baptista et al. (1992); (12) Heinrich et al. (1994); (13) Gjevik et al. (1997); (14) Rabinovich et al. (1998); (15) Diário de Noticias (1969); (16) Diário da Manhã (1969); (17) Al Alam (1969); (18) Kaabouben et al. (2008); (19) Soloviev (1990); (20) USGS online database; (21) Tinti et al., 2005) ; (22) Alasset et al., 2006; (23) Tel et al., 2004 ; (24) Yelles-Chaouche (1991).

\subsection{The 365 tsunami}

On $365 \mathrm{AD}$, an earthquake with its epicenter estimated at $35^{\circ} \mathrm{N}, 23^{\circ} \mathrm{E}$ struck the eastern Mediterranean close to the island of Crete, generating a tsunami that affected almost the entire eastern Mediterranean region (Tinti et al., 2005). The Spanish tsunami catalogue does not mention this event; probably it was not observed in the western Mediterranean. As we could not find any information describing this event in the Moroccan documents we do not include this event in the tsunami catalogue of Morocco.

\subsection{The 22 September 1522 tsunami}

For this event, all references are foreign but they confirmed the observation of a tsunami in northern Morocco on the 22 September 1522. We could not find any information in Maghrebian documents. According to the letter sent to Marquis of Vila Real several tsunami waves were observed at the port of Almeria, between 08:00 and 09:00 a.m.; the village of Badis Ghomera, located close to the Mediterranean coast suffered the impact of the tsunami that flooded most of the village (Varelas, 1984).

Many references in El Mrabet (2005) reported a strong earthquake felt in San Miguel Island, Andalusia (Spain) and several northern areas of Morocco: Fez, Tetouan and Bades. Intensity is estimated X (MSK) in Almeria. While there is no evidence for any tsunami on the Portuguese coasts (Baptista and Miranda, 2009), there is strong evidence for tsunami effects in Bades Ghomera, on the Morocco Mediterranean coast, where both the effect of giant sea waves and a dev- astating earthquake are described in the archive municipal Constance: as a terrible earthquake in a protected Palace of the Kingdom of Fez.

We conclude that the Azores and the Mediterranean event are different and that this event must be included in the Moroccan tsunami catalogue, for the Mediterranean domain.

\subsection{The 9 October 1680 tsunami}

The epicentre of the 9 October 1680 earthquake located near Malaga, struck Spain and led, on the northern Moroccan coast, to abnormal giant tsunami waves. The tsunami was observed on the southern coasts of Spain (rising sea $-5 \mathrm{~m}-$ in the harbour of Malaga) and in the north of Morocco (El Mrabet, 1991).

\subsection{The 1733 tsunami}

Soloviev (1990) presents a tsunami in 1733 that might have been observed in Tangier and Algiers. It is classified as "likely" tsunami and the cause is unknown. No data was found in Morocco historical descriptions and it is not in the seismic catalogue. This event is included in the tsunami catalogue for Morocco with reliability 0 .

\subsection{The 9 October 1790 tsunami}

Both the main shock and the aftershocks of the 9 October 1790 earthquake were felt in Morocco. Several documents confirm that the coast of Spain Almeria up to Carthage had suffered the impact of this quake (Marinas, op. cit., P.2, in El Mrabet, 2005); the author cites the details of the tsunami 

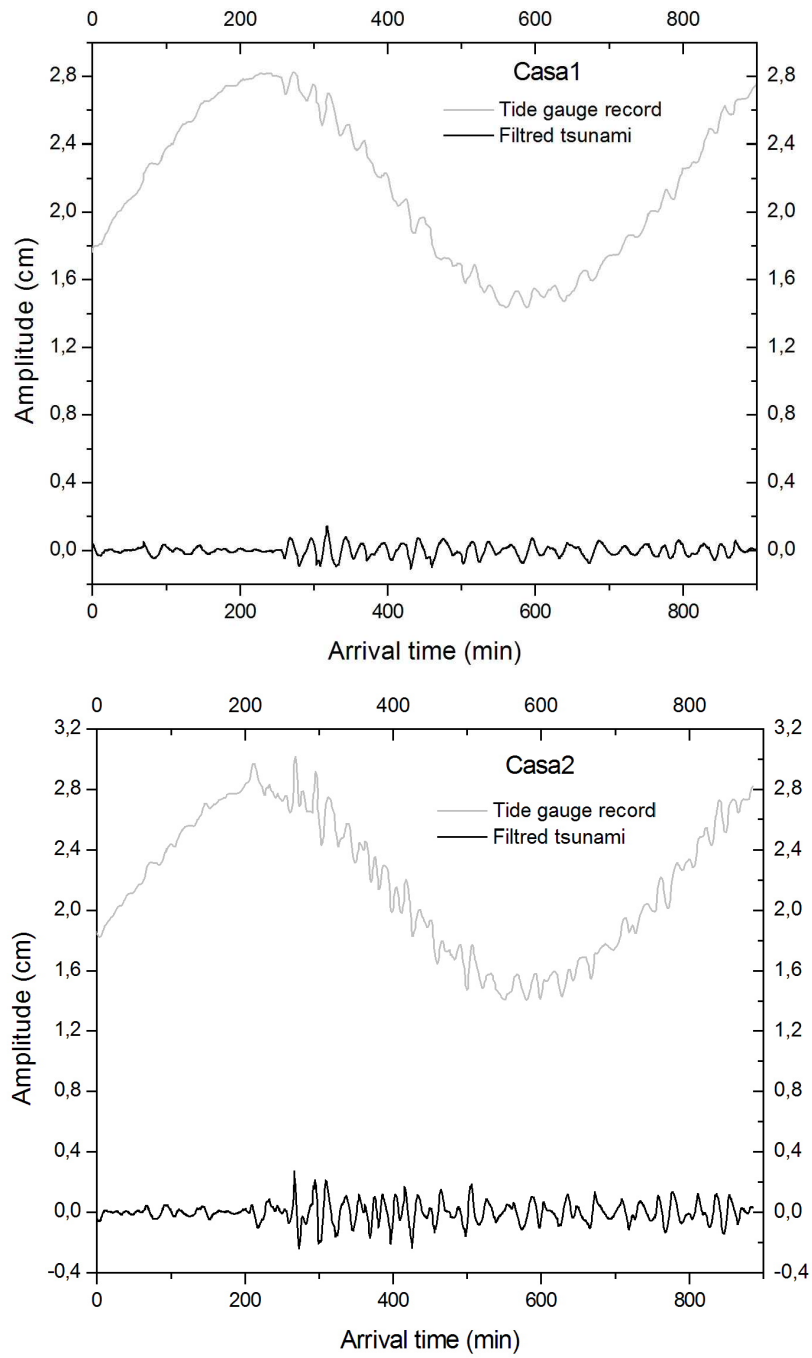

Fig. 4a. The tide records of the Casablanca transversal pier and small darse (4a) and Esssaouira (former Mogador) (4b) for the 25 November 1941 tsunami.

impact on the Algerian coasts. The maximum inundation distance at Almeria is noticeable in the dry land. Information about tsunami waves on the Moroccan coast are not find, but given the importance of the tsunami event on Algeria coast and its manifestation on the southern coast of Spain, let's us not exclude the evidence of its impact on the northern Moroccan coasts.

\subsection{The 21 August 1856 tsunami}

On the 21 August 1856, at about noon, an earthquake struck the coast of the province of Constantine and Bijaya. In Djidjelli, the earthquake was particularly severe and tsunami waves were observed: a strong withdraw of $35 \mathrm{~m}$, followed by an advance of the sea of $105 \mathrm{~m}$, over the beach, at Bejaya coast (Aucapitaine, 1856). El Mrabet (2005), the 21 and 22 August 1856 events, are well documented on the coast of

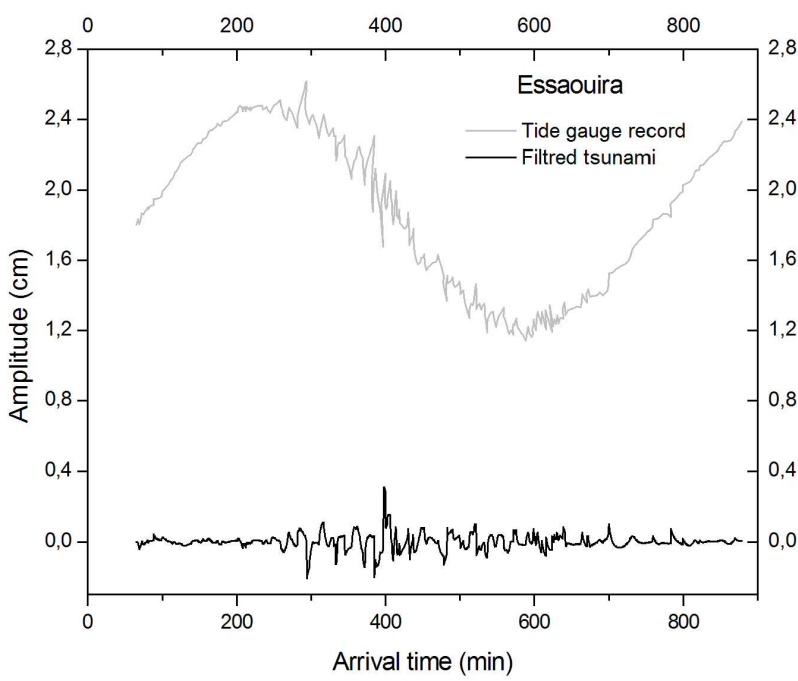

Fig. 4b. The tide records of the Casablanca transversal pier and small darse (4a) and Esssaouira (former Mogador) (4b) for the 25 November 1941 tsunami.

Algeria and the same for the tsunami waves. The earthquake was felt in Nice, Sicily and St. Peter in Sardinia, where it caused tsunami waves. This event was attributed an intensity of $\mathrm{X}$ on the Mercalli scale. This event can be improbably observed on the Moroccan coasts.

\subsection{The 10 October 1980 tsunami}

The earthquake of 10 October 1980 occurred at 03:39:09 p.m., the epicentre coordinates are $36.28^{\circ} \mathrm{N}$ and $1.68^{\circ} \mathrm{E}$ and the surface wave magnitude is 5.8 (in: http://earthquake.usgs.gov/eqcenter/eqarchives/significant/ sig_1980.php). At this stage we had no access to the Ceuta tide records.

\subsection{The 21 May 2003 tsunami}

The resulting tsunami on the Baleares Islands, is the most recently recorded in Mediterranean sea, following the $\mathrm{Mw}=7$ Boumerdes (Algeria) earthquake on the 21 May 2003 of magnitude. The sea disturbances were observed on the south eastern coasts of the Mallorca and Minorca Islands, also in the Ibiza (Baleares). Eyewitnesses reported wave heights of two meters and an average period of 10-12 min in Mallorca. The tide gauge localized in the Palma de Mallorca shows a maximum height of about $60 \mathrm{~cm}$, with peak to peak amplitude of $1.17 \mathrm{~m}$ (Tel et al., 2004).

The earthquake was not felt in Morocco, although it was recorded by the broadband seismic network. We could not find any documents of sea agitation in Morocco newspapers.

Tinti et al. (2005) claimed for negligible tsunami effects at Costa Blanca in Spain, concluding that almost all North Africa shoreline and the west coast of Spain should have 


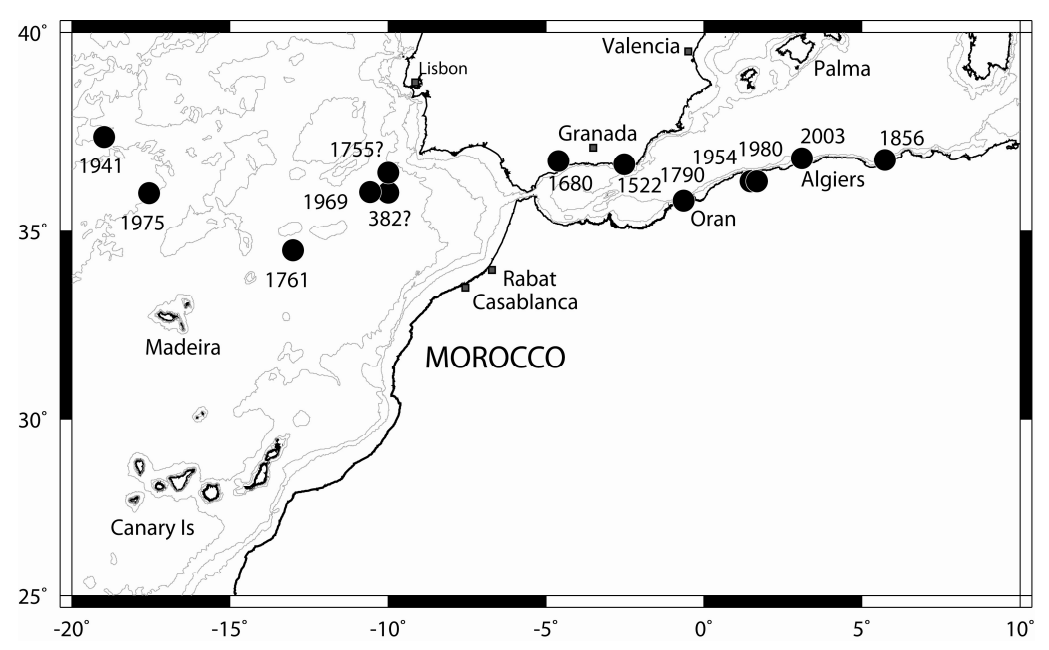

Fig. 5. Map of tsunami events which affected the Moroccan coasts.

been attacked by small waves. Alasset et al. (2006), shows the patterns for two different earthquake models; for both models we can observe that most energy radiates towards the Balearic Islands and the coast of Spain. At this stage we had no access to the Ceuta tide records. This event will be included in the Morocco catalogue with reliability 0.

\section{Discussion and conclusions}

After examining the descriptions quoted in Morocco historical documents, previous works about tsunamis in the Iberian Peninsula and available instrumental records, we established a preliminary list of possible tsunami events on the Moroccan coast which is presented at Table 3. The structure of this table follows Tinti and Maramai $(1996,1999)$ and Papadopoulos (2003). The Reliability parameter states the uncertainty on the occurrence of each event, using the 5 grade Iida scale, 0 means a "very improbable tsunami" and 4 to "definite tsunami. The intensity of the tsunami is described by the Sieberg-Ambraseys scale (Ambraseys, 1984) ranging from 1 for a very small tsunami only detected by tide gauges, to 6 for a catastrophic tsunami, spreading devastation along coastal areas. We indicate, for each case, the generation of a noticeable tsunami, the availability of historical documents and tide records in Morocco and the likelihood classification attributed in GITEC catalogue (Tinti et al., 1999). This list allows us to elaborate the map of the tsunamis on the Moroccan coast as shown in the Fig. 4.

Among the earthquakes included in the Morocco earthquake catalogues (Palaez et al., 2007) seven events had definitive tsunami effects and other thirteen probably generated also tsunamis affecting the Morocco coast. The most devastating event was the 1 November 1755 and secondly those of the 22 September 1522 and the 9 October 1680. Ac- cording to the available descriptions, the affected areas are mainly Badis Ghomera (Al Hoceima), Tetouan, Melilla in the Mediterranean side, while in the Atlantic side Tangier, Larache, Salé, El Jadida, Essaouira, Safi and Agadir.

It is possible that other events occurred, but as far as we know there are no witnesses' reports, nor news on the Moroccan journals or tide records.

In this paper, we gather and compile all the available information in historical records or established recently on the historical and instrumental tsunamis from the Atlantic Ocean and Mediterranean sea and that could have affected Moroccan coasts. This study allows us to assess our state of knowledge in this field, in an area where tsunami information is still scarce, and integrate it for the risk assessment on the Moroccan coasts. The event list developed shows that Morocco is subject to major destructive earthquakes and tsunamis in the Atlantic and probably in the Mediterranean coasts, Moroccan coasts are submitted to a clear risk of tsunamis, we have identified infrequent disasters that have occurred in the past and which require a reassessment of information so that they can be taken into account in future prevention programs. An action plan for the management of seismic and tsunami risks should be seen as a priority issue and an obligatory document taken into account for land use.

This compilation is of most importance for tsunami hazard assessment and these data should be included in the historical database of the NEAMTWS-IOC UNESCO (North East Atlantic, meditteranean and adjacent seas, tsunami warning system of the IOC- United Nations and a contribution to NEAREST and TRANSFER EU research projects.

Until now there is a lack of sedimentological evidence for tsunami deposits in the Moroccan coasts. To be able to complete the catalogue, and to include the most significant events, much more effort must be directed in this sense. 
Acknowledgements. The authors wish to thank T. El Mrabet for useful discussions on historical seismicity of Morocco, R. Omira for his kind cooperation in clarifying the location of old cities, J. M. Miranda (University of Lisbon) for reviewing of the manuscript, P.-L. Blanc for making available some French manuscripts. This study was sponsored by bilateral agreement between Portugal and Morocco, GRICES Portugal (MCTES) and by NEAREST 6FP, 37110 project.

Edited by: S. Tinti

Reviewed by: Y. Altinok and another anonymous referee

\section{References}

Al Alam Newspaper, 1 and 2 March, Morocco, 1969.

Alasset, P.-J., Hebert H., Maouche, S., and Calbini, V. : The tsunami inducec by the 2003 Zemmouri earthquake $(\mathrm{Mw}=6.9$, Algeria): modelling and results, Geophys. J. Int., 166(93), 213-226, doi: 10.111/j.1365-246X2006.02912x, 2006.

Aucapitaine, M.: Note sur le tremblement de terre ressenti en Algerie du 21 au 25 août, C. R. Acad. Sc. Paris, 2éme, semestre, T. XLIII, 16, 765 pp., 1856.

Baptista, M. A. and Miranda, J. M.: Revision of the Portuguese catalog of tsunamis, Nat. Hazards Earth Syst. Sci., 9, 25-42, 2009, http://www.nat-hazards-earth-syst-sci.net/9/25/2009/.

Baptista, M. A, Miranda, J. M., and Luís, J. F.: In Search of the 31 March 1761 Earthquake and Tsunami Source, Bul. Seismol. Soc. of America, 96, (2), 713-72 1, 2006.

Baptista, M. A., Miranda, J. M., Chierici, F., and Zitellini, N.: New study of the 1755 earthquake source based on multi-channel seismic survey data and tsunami modeling, Nat. Hazards Earth Syst. Sci., 3, 333-340, 2003,

http://www.nat-hazards-earth-syst-sci.net/3/333/2003/.

Baptista, M. A., Miranda, P. M. A., and Mendes Victor, L.: Maximum Entropy Analysis of Portuguese Tsunami: The Tsunamis of 28/02/1969 and 26/04/1975, Sc. of Tsunami Hazards, 10 (1), 9-20, 1992.

Blanc, P.-L.: Earthquakes and tsunami in November 1755 in Morocco: a different reading of contemporaneous documentary sources, Nat. Hazards Earth Syst. Sci., 9, 725-738, 2009, http://www.nat-hazards-earth-syst-sci.net/9/725/2009/.

Brito, F. B.: Monarquia Lusitana, Ed. Facsimile, Lisboa Imprensa Nacional - Casa da Moeda, 1973-88, 1597.

Buforn, E., Udias, A., and Colombas, M.: Seismicity source of the mechanisms and tectonics of the Azores-Gibraltar plate boundary, Tectonophysics, 152, 89-118, 1988.

Debrach, J. : Raz de marée d'origine sismique enregistrée sur le littoral atlantique du Maroc (in french), Service de Physique du Globe et de Météorologie, Annales, Maroc, 1946.

Diário da Manhã, 1 de Março de 1969, Lisboa, 1969(in Portuguese).

Diário de Notícias, 1 de Março de 1969. Lisboa, 1969(in Portuguese).

El Alami, S. O. and Tinti, S.: A preliminary evaluation of the tsunami hazards in the Moroccan coasts. Sc. of Tsunami Hazards, 31-38, 1991.

El Mrabet, T. : La sismicité historique du Maroc (en arabe), Thèse de $3^{\text {éme }}$ cycle, Faculté des lettres et des sciences humaines, Uni- versité Mohammed V. Rabat, 291 pp., 1991(in arabe).

El Mrabet, T. : Les grands séismes dans la région maghrébine, Thèse d'état, Faculté des lettres et des sciences humaines, Université Mohammed V. Rabat, 435 pp., 2005(in arabe).

Fernandes, R. M. S., Miranda, J. M., Meijninger, B. M. L., Bos, M. S., Noomen, R., Bastos L., Ambrosius, B.A.C., and Riva, R.E.M.: Surface Velocity Field of the Ibero-Maghrebian Segment of the Eurasia-Nubia Plate Boundary, Geophys. J. Int., 1, 315-324, 2007.

Fowke, Th.: An account of the earthquake in Barbary, inlosed in a letter from General Fowke, Governor of Gibraltar, to the Right Honourable Henry Fox, Philosophical Transactions, Vol. XLIX, part I, for the year 1756, 428-432, 1756.

Anonymous: Copia de Huma Carta Escrita pelo Padre Guardiam do Real Convento de Maquinés e Vice-Prefeito Das Santas Missoens, que nas partes da Barbaria conserva a Religiosa Provincia de São Diogo, Dos RR. PP. Franciscanos Descalços, ao Padre Procurador dellas, Lisboa, , Imprenta de Antonio Sanz, Calle de La Paz, Madrid, 8 pp., 1756(in spanish).

Gazeta de Lisboa, Mazagão, 25 de Janeiro de 1756, 1756(in Portuguese).

Gazette de Cologne: Africa De Ceuta, le 20 Novembre, 1756.

Gazette Française d'Amsterdam, Suite des Nouvelles d'Amesterdam du 26 Decembre 1755, 1756

Gjevik, B., Pedersen, G, Dybesland, E., Harbitz C. B, Miranda, P. M. A., Baptista, M. A., Mendes-Victor, L., Heinrich, Ph., Roche, R., and Guesima, M.: Modelling tsunamis from earthquake sources near Gorringe Bank southwest of Portugal, J. Geophys Res., 102, C13, 27931-27949, 1997.

Goulven, J.: La Place de Mazagan sous la domination portugaise (1502-1769), Larose, Paris, France, 245 pp., 1917.

Gutscher, M. A., Baptista, M. A., and Miranda, J. M.: The Gibraltar Arc seismogenic zone (part 2): constraints on a shallow east dipping fault plane source for the 1755 Lisbon earthquake provided by tsunami modelling and seismic intensity, Tectonophysics, 426, 153-166, 2006.

Heinrich, Ph., Baptista, M. A., and Miranda, P.: Numerical simulations of the 1969 tsunami along the Portuguese coasts, Preliminary Results. Sc. of Tsunami Hazards, 12, 1, 3-25, 1994.

Hirn, A., Haessler, H., Hoang, T., Wittlinger, G., Mendes Victor, L.: Aftershock Sequence of the 1 January 1980, Earthquake and Present Day Tectonics in the Azores, Geophys. Res. Lett., 7, 501-504, 1980.

Jiménez-Munt, I., Fernàndez, M., Torne, M., and Bird, P.: The transition from linear to diffuse plate boundary in the AzoresGibraltar region: results from a thin sheet model. Earth and Planetary Science Letters., 192, 175-189, 2001.

Johnston, A.: Seismic moment assessment of earthquakes in stable continental regions - III, New Madrid, 1811-1812, Charleston 1886 and Lisbon 1755, Geophys. J. Int., 126, 314-344, 1996.

Kaabouben, F., Iben Brahim, A., Toto, E., Baptista, M. A., Miranda, J. M., Soares, P., and Luis, J. F.: On The Focal Mechanism of the 26 May 1975 North Atlantic Event: Contribution From Tsunami Modeling, J. Seismol., 12 (4), 575-583, 2008.

Kadiri, M. T. E.: Nacher Al Mathani Lahl lkarn lhadi Acharwa thani, Casablanca, 412 pp., 1982(in Arabic).

Levret, A. : The Effects of the 1 November 1755 Lisbon Earthquake in Morocco, Tectonophysics, 193, 83 pp, 1991.

Lynnes, C. S. and Ruff, L. J.: Source process and tectonic 
implications of the great 1975 North Atlantic earthquake, Geophys. J. R. Astr. Soc., 82, 497-510, 1986.

Mason, A.: Letter to the Reverend Thomas Birch, D. D. Secretary to the Royal Society, relating to an extraordinary agitation of the Sea there, 31st of March 1761, Philos. T. R. Soc. A., 52, 477478, 1761.

Mendonça, J. M.: Historia Universal dos Terremotos, Lisboa, Officina de A. V. Silva, Biblioteca Nacional de Lisboa, 272 pp., 1758.

Moreira, V. S.: Tsunamis observados em Portugal, Publicacao GEO 134, Serviço Meteorologico Nacional, 17 pp, 1968.

Morel, J. L. and Meghraoui, M.: Gorringe-Alboran-Tell tectonic zone: a transpression system along the Africa-Eurasia plate boundary, Geology, 24, 755-758, 1996.

Navarro-Neumann, M. M.: Ensayo sobre la sismicidad del suelo espagñol, Boletin de la real Sociedad de Historia Natural, 83$109,1917$.

Papadoupolos, G.: Tsunami hazard in the Eastern Mediterranean: strong earthquakes and tsunamis in the Corinth Gulf, central Greece, Nat. Hazards, 29:437-464, 2003.

Pelaez, J. A., Chourak, M., Tadili, B., Ait Brahim, L., Hamdache, M., Casado, L. C., Solares, J. M. M., and Martinez, J. M.: A Catalog of Main Moroccan Earthquakes from 1045 to 2005, Seismological Research Letters, 78, 614-621, 2007.

Rabinovich, A. B., Miranda, P., and Baptista, M. A.:. Analysis of the 1969 and 1975 Tsunamis at the Atlantic Coast of Portugal and Spain, Oceanology , 38, 4, 463-469, 1998.

Roux, G.: Notes sur les tremblements de terre ressentis au Maroc avant 1933, Mém. Soc. Scien. Nat. Maroc, XXXIX; 42-71, 1934

Sella, G. F., Dixon, T. H., and Mao, A.: REVEL: A model for Recent plate velocities from space geodesy, J. Geophys. Res., 107, 2081, doi:10.1029/2000JB000033, 2002.

Solares, J. M. M. and López Arroyo, A.: The great historical 1755 earthquake. Effects and damage in Spain, April 2004, J. Seismol., 8(2), 275-294(20), 2004.

Soloviev, S.: Tsunamigenic Zones in the Mediterranean sea, Nat. Hazards, 3, 183-202, 1990.

Sousa, M. F.: Europa portuguesa segunda edicion correta, ilustarda y añadida en tantos lugares y con tales ventajas que es labor nueva por su autor Manuel de Faria y Sousa, Tomo I [-III], printed by Craesbeeck de Mello, d' Antonio, 1678-1680, Biblioteca Nacional de Lisboa, Portugal, Tomo I, 491 pp, Tomo II 224 pp, Tomo III 540 pp, 1678(in Portuguese).
Sylvanus, U.: The Gentleman's Magazine for December, printed by: D. Henry and R. Cave, St John's gate, 554-564, 1755.

Tel, E., Gonzalez, M,-J., Ruiz, C., Garcia, M.-J.: Sea level data archaeology: Tsunamis and Seiches and other phenomena. $4^{a}$ Assembleia Luso Espanhola de Geodesia e Geofísica Figueira da Foz 2004, $4^{a}$ Asemblea Hispano Portuguesa de Geodesia y Geofisica., Portugal, 2004.

Tinti, S. and Maramai, A.: Catalogue of tsunamis generated in Italy and in Côte d'Azur, France: a step towards a unified catalogue of tsunamis in Europe, Ann. Geofis., 39, 1253-129, 1996.

Tinti, S., Maramai, A.: Large tsunamis and Tsunami Hazard from the New Italian Tsunami Catalog, Phys. Chem. Earth (A), 24, no. 2, 151-156, 1999.

Tinti S., Baptista, M. A., Harbitz, C. B., and Maramai, A.: The unified European catalogue of tsunamis: a GITEC experience, Proc. International Conference on Tsunamis, Paris, 26-28 May 1998, 84-99, 1999.

Tinti, S, Armigliato, A., Pagnoni, G., and Zaniboni, F.: Scénarios of giant tsunamis of tectonic origin in the Mediterranean, ISET Journal of Earthquake Technology, Paper 464, 4, 171-188, 2005.

Varelas, H.: Una relacion Alemana sobre et terremoto de Andalucia, Marruecos y Azores del ano 1522, 1984.

Anonymous: Verdadera Relacion, del lamentable estrago que ha ocasionado el horrorozo terremoto ; acaecido el dia primero de Noviembre del Año de 1755 en la peninsula de España, Reyno de Portugal, Alemania, Cantones Suizos, Bohemia y Paises de Africa com un extracto de todas las desgracias y ruinas. Sacado de las cartas y relaciones autenticas de cada parage. Barcelona : Por Pablo Campins, impressor à la Calle de Amargos, 6 pp., 1755(in Spanish).

Zitellini, N., Mendes, L., Cordoba, D., Dañobeitia, J., Nicolich, R., Pellis, G., Ribeiro, A, Sartori, R, and Torelli, L. : Source of the 1755 Lisbon earthquake and tsunami investigated, Eos Trans. AGU, 82, (26), 285-291, 2001.

Yelles-Chaouche: Coastal Algerian earthquakes: A potential risk of tsunamis in western Mediterranean, Sci. Tsun. Hazards, 9(1), special issue, 47-54, 1991. 